\title{
Meningkatkan Pemahaman Peserta Didik pada Mata Kuliah Kajian Matematika SMP dengan Metode Tutor Sebaya Melalui Diskusi Kelompok dalam Kegiatan LSLC
}

\author{
Purwati $^{1)}$, Jeinne Mumu ${ }^{1)}$, Benidiktus Tanujaya ${ }^{1)}$ \\ Jurusan Pendidikan Matematika, FKIP, Universitas Papua \\ p.purwati@unipa.ac.id
}

\begin{abstract}
This research was the qualitative research that aimed to improve students understanding of junior high mathematics study. In accordance with the object to be studied, then this research is done in 3 times open class consisting of the plan, do, and see for each cycle, with the subject of research was the students of mathematics education department of FKIP UNIPA whom contracting subjects junior mathematics studies. To improve students understanding of the material, implementation of peer tutor methods was continuously modified based on the findings of each cycle. Based on the results of the implementation of Lesson Study as much as 3 cycles obtained the concluded that the learning outcomes of learners used peer tutor approach that modified each cycle has a significant increase. This was evident from students who answered the test correctly given at the end of each meeting. In the first cycle, from 27 students only 4 who can answer the test correctly that is equal to $14.81 \%$, the second cycle, from 27 learners only 10 which was able to answer the test correctly that was equal to 37,04\%, whereas in cycle III, from 26 students 21 students able to answer correctly that was equal to $80,77 \%$
\end{abstract}

Keywords : Peer Tutor, Group Discussion, Learning Outcomes, Lesson Study

his is an open access article distributed under the Creative Commons 4.0 Attribution License, which permits unrestricted use, distribution, and reproduction in any medium, provided the original work is properly cited $\odot 2018$ by author and Universitas Negeri Padang.

\section{PENDAHULUAN}

Jurusan Pendidikan matematika yang bernaung dibawah Fakultas Keguruan dan Ilmu Pendidikan Universitas Papua (FKIP UNIPA) merupakan salah satu Lembaga Pendidikan Tenaga Kependidikan (LPTK) di Manokwari Papua Barat. Peserta didik yang masuk ke LPTK, khususnya program pendidikan matema tika, secara khusus akan disiapkan untuk men jadi guru matematika. Guru merupakan kompo nen penting dalam proses pendidikan. Undangundang No. 14 tahun 2005 tentang Guru dan Dosen pasal 4 menegaskan bahwa guru sebagai agen pembelajaran yang berfungsi untuk mening katkan mutu pendidikan nasional. Guna melak sanakan fungsinya dengan baik, guru wajib untuk memiliki syarat tertentu, salah satunya kompetensi (Miarso, 2008). Terkait dengan hal tersebut pemerintah Indonesia mengeluarkan Undang-Undang No 14 tahun 2005 tentang kompetensi seorang guru. Guru diharuskan memiliki kompetensi pedagogik, kompetensi kepribadian, kompetensi sosial, dan kompetensi profesional.

Salah satu upaya untuk mewujudkan hal tersebut, terpenuhinya seluruh kompetensi yang diharapkan tertanam pada peserta didik, maka pada LPTK peserta didik dibekali mata kuliahmata kuliah yang relevan. Salah satu mata kuliah wajib yang mampu menjadi bekal peserta didik pada saat Program Latihan Profesi (PLP) adalah mata kuliah Kajian Matematika SMP. Mata kuliah ini mengkaji tentang materi-materi SMP sesuai dengan kurikulum yang sedang berjalan. Setelah memprogram mata kuliah ini peserta didik diharapkan telah menguasai materi SMP, mampu membuat peta konsep berdasarkan silabus dan mengembangkan materi dari peta konsep yang telah dibuat. Dengan menguasai materi yang akan diajarkan maka akan memi nimalisasi kesalahan konsep peserta didik yang diajar. Faktor penyebab siswa melakukan kesa lahan dalam menyelesaikan soal adalah kurang nya kemampuan membaca siswa dan siswa tidak memahami atau lupa terhadap konsep materi yang diajarkan (Purwati dan Haryanto 2017).

Selama ini, proses pembelajaran pada rumpun pendidikan matematika dilihat dari ketuntasan belajar dan hasil belajar peserta didik, tidak terdapat indikasi masalah yang berarti seperti pada mata kuliah lainnya. Namun, pada proses pembelajaran yang berlangsung di kelas hingga saat ini, masih berpusat pada dosen 
atau sering disebut juga teacher centered atau dikenal dengan pendekatan tradisional (Utami, dkk: 2011). Dalam pembelajaran tersebut, dosen sebagai individu yang lebih aktif dalam mengajar dan peserta didik berperan sebagai objek yang menerima pengetahuan dengan pasif. Meskipun beberapa metode sudah coba diterap kan seperti metode diskusi, namun peserta didik masih belum merespon dengan baik. Mereka masih pasif dalam mengemukakan pendapat, diskusi lebih banyak didominasi oleh peserta didik yang itu-itu saja. Jika hal ini dibiarkan maka yang akan memahami materi yang disam paikan hanya sebagian kecil. Untuk mengatasi hal tersebut Dosen perlu menerapkan metode pembelajaran yang mampu mengaktifkan peser ta didik. Salah satunya adalah melalui metode tutor sebaya.

Terkadang seorang peserta didik lebih mudah menerima keterangan yang diberikan teman sebayanya, karna dalam berkomunikasi mereka bisa menggunakan bahasanya sendiri sehingga tidak ada rasa enggan dan malu untuk bertanya. Tutor sebaya adalah seorang atau beberapa orang peserta didik yang ditunjuk dan ditugaskan untuk membantu peserta didikpeserta didik tertentu yang mengalami kesulitan belajar. Penggunaan model pembelajaran tutor sebaya dalam pembelajaran matematika meru pakan salah satu cara yang diharapkan dapat memberi peran aktif bagi peserta didik, agar mereka mempelajari dengan sungguh- sungguh materi yang diberikan. Sehingga diharapkan dengan menggunakan model pembelajaran tutor sebaya ini, peserta didik lebih mudah menyerap materi yang diajarkan, dan pada akhirnya peser ta didik tidak mengalami banyak kesulitan dalam pembelajaran matematika (Sabbarudin, 2009).

Akan tetapi, sebaik apapun metode pembelajaran, guru harus pula memperhatikan beberapa kelemahan dari diterapkannya metode pembelajaran. Khusus metode tutor sebaya, (Djamarah dkk, 2006) menjelaskan bahwa kelemahan dari metode pembelajaran ini antara lain:

1. Peserta didik yang dibantu sering belajar kurang serius, karena hanya berhadapan dengan kawannya, sehingga hasilnya kurang memuaskan.

2. Ada beberapa anak yang menjadi malu bertanya, karena takut rahasinya diketahui kawannya.
3. Pada kelas-kelas tertentu pekerjaan tutoring ini sukar dilaksanakan, karena perbedaan kelamin antara tutor dengan peserta didik yang diberi program perbaikan.

4. Bagi guru sukar untuk menentukan seorang tutor yang tepat bagi seorang atau beberapa orang peserta didik yang harus dibimbing.

5. Tidak semua peserta didik yang pandai atau cepat waktu belajarnya dapat mengerja kannya kembali kepada kawan-kawannya.

Untuk mengatasi kelemahan tersebut metode tutor sebaya disandingkan dengan dis kusi dan persentase kelompok untuk mengaktif kan semua anggota kelompok. Cara diskusi kelompok yang digunakan dalam proses belajar mengajar untuk menyampaikan materi pembela jaran dimana peserta didik belajar bekerjasama memberikan argumentasi dan ide-ide dalam kelompok-kelompok kecil atau kelompok besar secara kolaboratif dengan struktur kelompok yang heterogen dan memiliki kemampuan yang berbeda-beda, sehingga peserta didik dapat memanfaatkan teman sejawat (peserta didik lain) sebagai rekan dalam memecahkan masalah atau mendiskusikan materi-materi yang telah ditentukan kepada kelompok-kelompok tersebut, dan mereka dapat saling membantu dan tukar menukar pendapat dan ide yang pada akhirnya dapat merangsang peserta didik lebih bergairah dalam belajar, dan dalam sistem ini dosen sebagai fasilitator dan pengarah efektifitas pembelajaran. Selain itu tujuan persentase di akhir pertemuan menjadi langkah untuk memaparkan hasil pemahaman mereka terhadap materi yang mereka kaji, sekaligus menjadi penarikan kesimpulan sekaligus klarifikasi jika ada kesalahan dalam memahami materi berdasarkan hasil diskusi kelompoknya.

Kurangnya kemampuan peserta didik dalam memahami materi tidak terlepas dari peran tenaga pendidik dalam mempersiapkan perangkat pembelajaran, melaksanakan pembela jaran, dan mengevaluasi proses pembelajaran. Dosen yang profesional adalah salah satu faktor penentu keberhasilan proses belajar mengajar di kelas. Kemampuan merancang perangkat pem belajaran yang berkualitas menunjukkan ke siapan tenaga pendidik dalam mengajar (Khotimah, 2017). Salah satu cara yang dapat digunakan untuk mempersiapkan itu semua adalah dengan membiasakan tenaga pendidik melakukan Lesson Study. Lesson Study diarti kan sebagai suatu model pembinaan profesi pendidik melalui pengkajian pembelajaran 
secara kolaboratif dan berkelanjutan berlandas kan prinsip-prinsip kesejawatan dan mutual learning untuk membangun komunitas belajar. Dalam melaksanakan Lesson Study, pendidikpendidik secara kolaboratif (Susilo, 2013):

1. Mempelajari kurikulum, dan merumuskan tujuan pembelajaran dan tujuan pengem bangan kecakapan hidup siswa

2. Merancang pembelajaran untuk mencapai tujuan tersebut.

3. Melaksanakan dan mengamati suatu re search lesson ("pembelajaran yang dikaji") untuk kemudian

4. Melakukan refleksi untuk mendiskusikan pembelajaran yang dikaji dan menyem purnakannya, dan merencanakan pembela jaran berikutnya.

Pelaksanaan Lesson Study ditekankan pada 3 tahap yaitu Plan (merencanakan atau merancang), Do (melaksanakan), dan See (meng amati, dan sesudah itu merefleksikan hasil pengamatan) (Sutopo dan Ibrohim, 2006). Adapun langkah-langkah dalam tiap tahap Lesson Study sebagai berikut :

1. Plan, Secara kolaboratif pendidik meren canakan pembelajaran yang berpusat pada peserta didik. Tahap perencanaan (Plan) bertujuan untuk menghasilkan rancangan pembelajaran yang diyakini mampu mem belajarkan siswa secara efektif serta mem bangkitkan partisipasi siswa dalam pembela jaran. Perencanaan ini dilakukan secara kola boratif oleh beberapa orang pendidik yang termasuk dalam suatu kelompok Lesson Study (jumlah bervariasi 6-10 orang). Biasanya ditetapkan dulu siapa pendidik yang akan menjadi Pengajar (Guru Model), kemudian guru model menyusun RPPnya. Para pendidik kemudian bertemu dan ber bagi ide menyempurnakan rancangan pem belajaran yang sudah disusun guru model untuk menghasilkan cara pengorganisasian bahan ajar, proses pembelajaran, maupun penyiapan alat bantu pembelajaran yang dianggap paling baik. Semua komponen yang tertuang dalam rancangan pembela jaran ini kemudian disimulasikan sebelum dilaksanakan dalam kelas. Pada tahap ini juga ditetapkan prosedur pengamatan dan instrumen yang diperlukan dalam penga matan.

2. Do, Seorang pendidik melaksanakan pem belajaran dengan Lesson Design dan Chap ter Design yang dihasilkan melalui plan.
Tahap pelaksanaan (Do) dimaksudkan untuk menerapkan rancangan pembelajaran yang telah direncanakan. Salah satu ang gota kelompok berperan sebagai guru model dan anggota kelompok lainnya mengamati. Fokus pengamatan diarahkan pada kegiatan belajar siswa dengan berpedo man pada prosedur dan instrumen yang telah disepakati pada tahap perencanaan, bukan pada penampilan pendidik yang sedang bertugas mengajar. Selama pembela jaran berlangsung, para pengamat tidak diperkenankan mengganggu proses pem belajaran walaupun mereka boleh merekam nya dengan kamera video atau kamera digital. Tujuan utama kehadiran pengamat adalah belajar dari pembelajaran yang sedang berlangsung.

3. See, Secara kolaboratif pendidik meref leksikan keefektifan pembelajaran dan sa ling belajar dengan prinsip saling meng hargai dan memberikan hasil refleksi secara santun. Tahap pengamatan dan refleksi (See) dimaksudkan untuk menemukan kelebihan dan kekurangan pelaksanaan pembelajaran. Pendidik yang bertugas sebagai guru model mengawali diskusi dengan menyampaikan kesan dan pemi kirannya mengenai pelaksanaan pembela jaran. Kesempatan berikutnya diberikan kepada pendidik yang bertugas sebagai pengamat. Selanjutnya pengamat dari luar juga mengemukakan apa Lesson Learned yang dapat diperoleh dari pembela jaran yang baru berlangsung. Kritik dan saran disampaikan secara bijak tanpa merendahkan atau menyakiti hati pendidik yang membelajarkan, semuanya demi per baikan praktik ke depan. Berdasarkan semua masukan dapat dirancang kembali pembelajaran berikutnya yang lebih baik.

Berdasarkan latar belakang tersebut maka dirumuskan tujuan penelitian yaitu untuk meningkatkan pemahaman siswa terhadap materi pada mata kuliah Kajian matematika SMP yang menggunakan metode tutor sebaya dalam kegiatan LSLC.

\section{METODE PENELITIAN}

Subjek dalam penelitian ini adalah peserta didik pendidikan matematika angkatan 2016 yang mengontrak mata kuliah kajian matematika SMP yaitu sebanyak 27 peserta didik. Penelitian 
ini merupakan penelitian kualitatif dengan jenis penelitian tindakan kelas. Sedangkan desainnya mengacu pada model Kemmis \& McTaggart yang terdiri dari: (1) perencanaan; (2) tin dakan; (3) observasi; dan (4) refleksi (sesuai dengan langkah-langkah dalam Lesson Study Plan, Do, See). Sumber data pada penelitian ini berasal dari: (1) Tim LSLC Pendidikan matema tika yang terdiri dari 4 orang, (2) Peserta didik Pendidikan Matematika, (3) hasil rekaman audio visual selama proses pembelajaran berlangsung dan (4) hasil tes peserta didik (Tanujaya, 2016).

Teknik pengumpulan data pada penelitian ini dengan menggunakan lembar observasi dan hasil belajar peserta didik. Analisis data meng gunakan Triangulasi data yang terdiri dari: (1) mereduksi data; (2) menyajikan data; (3) mem buat temuan atau menarik kesimpulan.

\section{HASIL DAN PEMBAHASAN}

Pada kegiatan Lesson Study ini dilaksanakan tiga kali open lesson yang masingmasing diawali oleh kegiatan plan, dilanjutkan dengan kegiatan do dan diakhiri dengan kegiatan see pada setiap siklusnya. Berikut adalah uraian hasil setiap siklus.

\section{Siklus I}

Untuk Siklus I Plan dilakukan di ruangan Dosen Pendidikan matematika yang terdiri dari 4 orang. Pada tahap ini dengan teman-teman dosen dari pendidikan matematika, dosen model membahas rencana pembelajaran yang akan dilakukan dimulai dengan membuka diskusi dan menceritakan tentang mata kuliah dan masalah yang akan diselesaikan melalui Lesson Study. Masalah utama yang dihadapi adalah peserta didik sangat pasif dalam proses pembelajaran. Untuk mengatasi hal tersebut, para observer dan dosen model berdiskusi tentang rencana penyelesaian masalah, yang dituangkan terlebih dahulu dalam pembuatan Chapter Design untuk materi pendahuluan pada mata kuliah kajian matematika SMP, yang selanjutnya dibuat kedalam beberapa lessons design. Berdasarkan hasil diskusi ditetapkan bahwa pendekatan pembelajaran yang akan digunakan yaitu dengan pendekatan pembelajaran dengan tutor sebaya. Tutor sebaya berarti peserta didik mengajar peserta didik lainnya atau yang berperan sebagai pengajar (tutor) adalah peserta didik. Tutor sebaya (peer teaching) ini memudahkan belajar, peserta didik berpartisipasi aktif, dan dapat memecahkan masalah bersama-sama, sehingga pemerataan pemahaman terhadap materi pembelajaran yang diberikan dapat tercapai (Febianti, 2014).

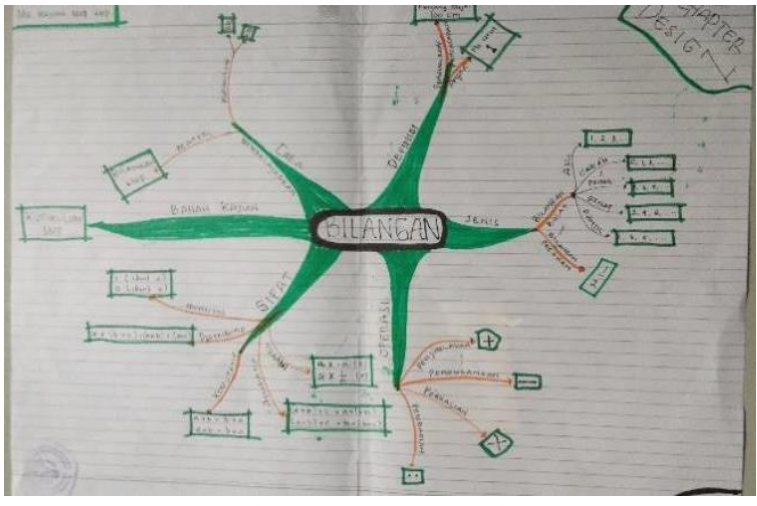

Pada kegiatan plan ini dihasilkan sebuah

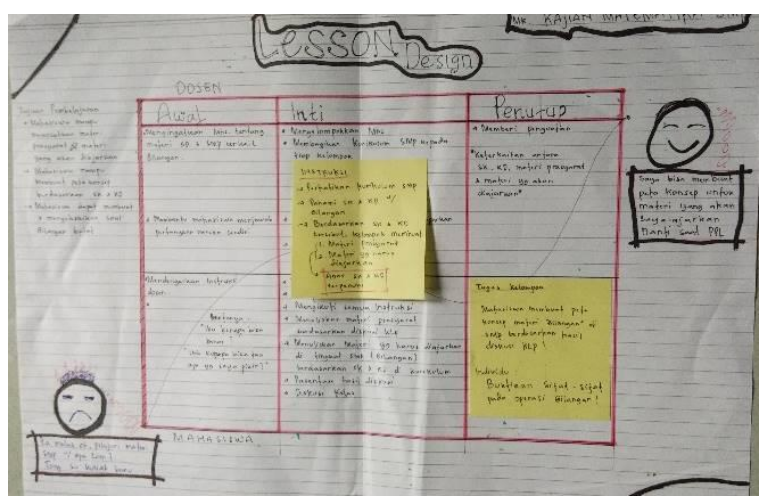

chapter design dan lesson design.

\section{Gambar 1. Chapter Design}

\section{Gambar 2. Lesson Design}

Do dilaksanakan berdasarkan lesson design yang telah dikembangkan pada kegiatan plan. Dosen model memberikan RPP dan lembar observasi yang telah dibuat berdasarkan lessons design kepada observer, selanjutnya melaksana kan proses pembelajaran yang diawali dengan pembagian kelompok. Tiap kelompok ditunjuk satu orang yang dianggap mampu menjadi tutor dalam kelompok tersebut. Kemudian dilanjutkan dengan pemaparan singkat deskripsi mata kuliah serta aturan-aturan dalam pembelajaran menggu nakan slide powerpoint. Dosen model membagi kan silabus SMP kepada tiap kelompok, dan menentukan materi untuk tiap kelompoknya. Bersama-sama dengan teman kelompoknya, tutor memimpin diskusi kelompok untuk membuat peta konsep berdasarkan silabus yang telah dibagikan. Peserta didik melaksanakan pembelajaran dengan serius dan tertib. Dosen 
observer melakukan pengamantan dengan mengisi lembar observasi. Peserta didik mem buat peta konsep pada kertas HVS dan dipre sentasekan di depan kelas. Dosen model menu tup pembelajaran dengan memberikan tugas kepada tiap kelompok untuk membuat materi SMP dari peta konsep yang telah mereka buat dari diskusi kelompok untuk dipresentasekan pada pertemuan selanjutnya. Setelah proses pembelajaran, dilanjutkan dengan pemberian tes untuk mengetahui pemahaman peserta didik terhadap materi yang telah diberikan. Hasil tes peserta didik disajikan pada tabel berikut:

Tabel 1. Hasil Tes Mahasiswa pada Siklus I

\begin{tabular}{|c|c|c|}
\hline $\begin{array}{c}\text { Jumlah Peserta } \\
\text { Didik }\end{array}$ & Benar & Salah \\
\hline 27 & 4 & 23 \\
\hline
\end{tabular}

Dari hasil tes terlihat hanya 4 peserta didik yang mampu menjawab dengan benar, tes yang diberikan yaitu sekitar $14,81 \%$. Rendahnya persentase peserta didik yang menjawab dengan benar terjawab melalui kegiatan see yang dila kukan dan berdasarkan hasil dokumentasi selama proses pembelajaran berlangsung.

Pada tahap refleksi dosen model dan observer membahas hasil observasi terkait jalan nya pembelajaran. Dosen model menemukan permasalahan bahwa peserta didik banyak yang kesulitan pada saat mencoba membuat peta konsep materi berdasarkan silabus dikarenakan mereka belum memahami istilah-istilah pada silabus, seperti standar kompetensi, kompetensi dasar dan indikator, selain itu dosen pengamat juga menemukan kelompok yang belum maksimal dalam diskusi, tutor tidak menjelaskan apa yang harus dilakukan pada teman-teman kelompoknya. Berdasarkan temuan tersebut maka dosen model dan observer memutuskan perlunya memperkenalkan garis besar istilahistilah dalam silabus, dan mengaktifkan semua anggota kelompok dalam diskusi selanjutnya. Untuk mengaktifkan anggota kelompok maka dosen model yang akan memilih anggota kelom pok yang persentase dan menjawab pertanyaan, dengan cara tersebut diharapkan fungsi tutor lebih diperhatikan, karena nilai kelompok ber gantung pada nilai semua anggota kelompoknya.

Berdasarkan hasil analisis pada siklus I dengan metode tutor sebaya diperoleh temuan bahwa dari diskusi kelompok yang dilakukan, tutor belum melaksanakan tugasnya dengan baik. Tutor masih sibuk dengan pemikirannya sendiri sehingga belum terlihat transfer ilmu dari tutor ke teman kelompoknya. Akibatnya tidak semua anggota kelompok memahami materi yang diberikan. Hal tersebut dibuktikan dengan hasil tes dari 27 peserta didik hanya 4 yang menjawab tes dengan benar yaitu sebesar $14,81 \%$.

\section{Siklus II}

Pada Siklus II Plan dimulai dengan mema parkan kembali lesson design yang disusun masih berdasarkan chapter design yang telah dihasilkan pada plan di siklus I, tetapi dengan memperhatikan masukan-masukan dan temuan pada siklus I. Dosen model menyerahkan foto copy perangkat pembelajaran, yaitu lesson de sign yang telah dibuat pada saat refleksi siklus I. Dosen model menjelaskan tentang perubahan langkah- langkah pembelajaran pada siklus I. Para observer dan dosen model berdiskusi tentang lesson design untuk siklus II. Dosen model dan observer menyepakati strategi pem belajaran yang akan diterapkan di kelas, berda sarkan hasil diskusi ditetapkan bahwa metode yang digunakan masih sama, hanya saja pada pelaksanaan presentase dosen model yang menunjuk langsung anggota kelompok untuk mempersentasekan, sehingga semua anggota kelompok harus siap dan menguasai materi kelompoknya. Dosen model menjelaskan bahwa pada siklus II indikator pembelajaran yang ingin dicapai adalah mampu mengembangkan dan menjelaskan kembali materi SMP berdasarkan peta konsep yang telah dihasilkan pada pertemuan sebelumnya.

Pelaksanaan pembelajaran pada siklus II berdasarkan lesson design yang dikembangkan berdasarkan temuan pada siklus I. Pembelajaran dimulai dengan menyiapkan kelompok yang akan persentase, dan peserta didik yang lain duduk berdasarkan kelompoknya. Dosen model menunjuk anggota kelompok sebagai moderator, dan menunjuk anggota lainnya secara bergantian dalam mempersentasekan materi kelompoknya moderator membuka sesi pertanyaan dosen model memberikan penguatan setelah persentase kelompok berakhir. dosen observer melakukan pengamatan dengan mengisi lembar observasi. Pembelajaran diakhiri pemberian tes terkait materi yang disampaikan kelompok penyaji. Hasil tes peserta didik disajikan pada tabel berikut :

Tabel 2. Hasil Tes Mahasiswa pada Siklus II 


\begin{tabular}{|c|c|c|}
\hline $\begin{array}{c}\text { Jumlah } \\
\text { Peserta Didik }\end{array}$ & Benar & Salah \\
\hline 27 & 10 & 17 \\
\hline
\end{tabular}

Dari hasil tes terlihat 10 peserta didik yang sudah mampu menjawab dengan benar, tes yang diberikan yaitu sekitar $37,04 \%$. Terjadi peningkatan persentase peserta didik yang mampu menjawab tes dengan benar. Namun peningkatan yang terjadi tidak terlalu signifikan. Untuk meningkatkan persentase tersebut maka dilakukan refleksi siklus II untuk menentukan lesson design pada siklus III.

Pada tahap refleksi dosen model dan dosen pengamat membahas hasil observasi. Dari hasil pengamatan observer, pada saat presentase masih ada kelompok yang sibuk dengan materi kelompoknya masing-masing, hal tersebut yang mengakibatkan diskusi kelompok menjadi kurang maksimal. Pada waktu dibuka sesi pertanyaan antusias kelompok lain untuk bertanya tidak ada, mereka hanya sibuk saling memandang. Ketika dosen model menunjuk satu kelompok untuk bertanya mereka akhirnya sibuk mencari pertanyaan. Dapat dipastikan mereka tidak memahami semua materi yang disajikan oleh kelompok penyaji. Untuk melihat hal tersebut, dosen model memberikan tes tentang materi yang telah disajikan. Dosen model menemukan fenomena pada kelompok penyaji bahwa penunjukan langsung yang dilakukan oleh dosen membuat semua anggota kelompok betul-betul bertanggung jawab pada materi kelompoknya, observer juga melihat tingkat penguasaan materi kelompok penyaji sangat baik. Dosen model mengusulkan untuk mengaktifkan diskusi maka akan ditunjuk satu kelompok penanya, jadi ketika kelompok penyaji selesai mempersentasekan materinya maka sesi pertama pertanyaan dari kelompok penanya, dan sesi kedua dari kelompok lain, dengan catatan tiap kelompok yang bertanya akan memperoleh nilai dan akan diakumulasikan pada akhir penilaian.

Berdasarkan hasil analisis pada siklus II dengan metode tutor sebaya dengan latar diskusi kelompok. Hasil refleksi dari siklus I menjadi acuan dalam mengaktifkan diskusi kelompok, dimana penekanannya yaitu agar semua anggota kelompok memahami materi, maka yang bertanggung jawab untuk mempersentasekan materi kelompok ditunjuk langsung oleh dosen. Hal tersebut cukup efektif karna semua anggota kelompok sudah memahami materi dengan baik. Hal tersebut terlihat dari persentase. Tiap anggota kelompok mampu menjelaskan materinya dengan baik. Namun ada beberapa temuan dari siklus II yaitu: Diskusi kelas tidak berjalan dengan baik, kelompok yang terlihat serius memperhatikan presentase ternyata sibuk mempelajari materinya masing-masing, hanya beberapa peserta didik saja yang memperhatikan materi yang dipresentasekan. Akibatnya dari 27 peserta didik hanya 10 yang menjawab tes dengan benar yaitu sebesar $37,04 \%$.

\section{Siklus III}

Plan pada siklus III dihadiri oleh empat dosen yang sekaligus berperan sebagai penga mat (observer) pada siklus I dan II. Dosen model menyerahkan fotocopy perangkat pembelajaran, yaitu lesson design yang dikembangkan berdasar kan chapter design pada siklus I dan hasil refleksi pada siklus II. Dosen model dan obser ver berdiskusi mengenai strategi pembelajaran yang akan diterapkan di kelas, berdasarkan hasil refleksi pada siklus II, bahwa untuk mengak tifkan diskusi maka akan ditunjuk kelompok penanya dan akan diberi kesempatan kepada tiap kelompok untuk mengumpulkan nilai melalui proses bertanya. Dosen model menjelaskan bahwa pada akhir pertemuan akan tetap diadakan tes untuk melihat sejauh mana pema haman peserta didik pada materi yang disajikan.

Pada tahap Do pelaksanaan proses pem belajaran kajian matematika SMP dimulai dengan penjelasan dari dosen model tentang aturan diskusi yang akan dilaksanakan, dan menunjuk satu kelompok sebagai kelompok penanya, dosen model juga menyampaikan akan ada sesi pertanyaan dan akan diberi kesempatan kepada semua kelompok untuk mengajukan pertanyaan, setiap pertanyaan akan diberi nilai dan akan diakumulasikan pada akhir penilaian. Kelompok penyaji mempresentasekan materi nya, pemateri ditunjuk langsung oleh dosen model secara bergantian sampai materi selesai. Kelompok penanya diberi kesempatan untuk menyanggah, bertanya, atau menyampaikan pen dapatnya. Pada sesi pertanyaan yang kedua, se mua kelompok berlomba-lomba untuk mengum pulkan nilai dengan bertanya. Do pada siklus III diakhiri dengan pemberian tes tentang materi yang disajikan. Hasil tes peserta didik disajikan pada tabel berikut.

Tabel 3. Hasil Tes Mahasiswa pada Siklus III 


\begin{tabular}{|c|c|c|}
\hline $\begin{array}{c}\text { Jumlah } \\
\text { Peserta Didik }\end{array}$ & Benar & Salah \\
\hline 26 & 21 & 5 \\
\hline
\end{tabular}

Jumlah peserta didik yang hadir pada pertemuan di siklus III hanya 26 peserta didik, tetapi dalam perhitungan persentase jumlah siswa yang menjawab tes dengan benar tetap menggunakan jumlah peserta didik di siklus I dan II yaitu 27 orang. Dari hasil tes terlihat 21 peserta didik yang sudah mampu menjawab dengan benar, tes yang diberikan yaitu sekitar $80,71 \%$. Peningkatan ini sangat signifikan.

Peningkatan yang signifikan tersebut sesuai dengan hasil refleksi proses pembelajaran pada siklus III. Dosen model dan observer membahas hasil observasi pada siklus III. Diskusi menjadi lebih maksimal, terlihat dari awal presentase hingga akhir presentase semua kelompok memperhatikan dengan seksama. Peran kelompok penanya juga dimanfaatkan dengan sebaik-baiknya mulai dari memberikan saran sampai memberi pertanyaan. Antusias kelompok lain dalam mengumpulkan nilai juga sangat tinggi. Hal tersebut terlihat dari semangat mereka untuk bertanya. Dosen model juga me lihat waktu yang diperlukan untuk menyelesai kan tes menjadi lebih sedikit.

Berdasarkan hasil analisis pada siklus III yang merupakan perbaikan dari siklus II, disarankan untuk mengaktifkan diskusi kelas maka ditunjuk satu kelompok penanya, jadi ketika kelompok penyaji selesai mempresentasi kan materinya maka sesi pertama pertanyaan dari kelompok penanya, dan sesi kedua dari kelompok lain, dengan catatan tiap kelompok yang bertanya akan memperoleh nilai dan akan diakumulasikan pada akhir penilaian. Hal tersebut membuat peserta didik fokus memper hatikan materi yang dipersentasekan, yang menarik adalah tanya jawab tiap kelompok menjadi aktif, mereka bersemangat untuk bertanya. Akibatnya berdampak pada tes di siklus III dari 26 peserta didik, sebanyak 21 peserta didik mampu menjawab dengan benar tes yang diberikan, yaitu sebesar $80,77 \%$. Hal ini menunjukkan semakin banyak siswa yang memahami materi yang disajikan dengan meto de pembelajaran tutor sebaya dengan latar diskusi kelompok dan berkompetensi dalam mengumpulkan nilai.

\section{KESIMPULAN}

Berdasarkan hasil pelaksanaan Lesson Study sebanyak 3 siklus diperoleh kesimpulan bahwa hasil belajar peserta didik dalam proses pembelajaran pada mata kuliah kajian mate matika SMP dengan menggunakan pendekatan tutor sebaya yang dimodifikasi disetiap siklus nya mengalami peningkatan yang signifikan. Hal tersebut terlihat dari banyaknya peserta didik yang menjawab dengan benar hasil tes yang diberikan di setiap akhir pertemuan pada siklus I dari 27 peserta didik hanya 4 yang mampu menjawab tes dengan benar yaitu sebesar 14,81\%, siklus ke II dari 27 peserta didik hanya 10 yang mampu menjawab tes dengan benar yaitu sebesar $37,04 \%$, sedangkan pada siklus ke III dari 26 peserta didik 21 orang mampu menjawab dengan benar yaitu sebesar $80,77 \%$.

Disarankan agar setiap dosen lebih kreatif menggunakan metode dalam proses perkuliahan, tidak terpaku pada satu metode. Kegiatan LSLC dapat meningkatkan kualitas dosen dalam poses pembelajaran, karena banyak hal yang akan ditemukan oleh observer pada saat proses pembelajaran. Hal tersebut digunakan untuk memperbaiki proses pembelajaran selanjutnya, agar tujuan pembelajaran dapat tercapai dengan baik.

\section{DAFTAR PUSTAKA}

Djamarah. (2006). Strategi Belajar Mengajar. Jakarta: Rineka Cipta

Febianti, YN. (2014). Peer Teaching (Tutor Sebaya) Sebagai Metode Pembelajaran Untuk Melatih Siswa Mengajar. Jurnal Pendidikan Ekonomi Vol 2 No 2.

Khotimah, RP. (2017). Pakom Pelatihan dan Pendampingan Penyusunan Perangkat Pembelajaran Matematika Berbasis Lesson Study. Jurnal Warta LPM.

Miarso, Y. (2008). Peningkatan Kualifikasi guru dalam perspektif Teknologi Pendi dikan. Jurnal Pendidikan Penabur. 7(10): 66-76

Mumu, J., Purwati., Nurhasanah., \& Tanujaya, B. (2017). Developing Vector Space Construction Capability through Ana logical Abstraction and Generalization Process in Lesson Study Activity Based On Papuan Wisdom "Satu Tungku Tiga Batu". Prosiding The 8th Inter national Confrence on Lesson Study 8(1),247-254. 
Nurhasanah, Farida. (2012). Membangun Keaktifan Mahasiswa Pada Proses Pembelajaran Mata Kuliah Perenca naan Dan Pengembangan Program Pembelajaran Matematika Melalui Pendekatan Kontruktivisme Dalam Kegiatan Lesson Study. Jurnal Infinity. 1(1): 62-78

Purwati, DS Haryanto. (2017). Analisis Kesalahan Siswa dalam Menyelesai kan Soal Cerita Bilangan Pecahan kelas VIII SMP 19 Manokwari. Prosiding Seminar Nasional UNCP Vol 3 No. 1.

Susilo, H. (2013). Lesson Study sebagai Sarana Meningkatkan Kompetensi Pendidik. Makalah Disajikan dalam Seminar dan Lokakarya PLEASE.

Sutopo., \& Ibrohim. (2006). Pengalaman IMSTEP dalam Implementasi Lesson Study. Makalah disajikan dalam pelatihan pengembangan Kemitraan LPTK-Sekolah dalam rangka Peningkatan mutu Pembelajaran MIPA di Yogyakarta.
Tanujaya, B., \& Mumu, J. (2016). Penelitian Tindakan Kelas: Panduan Belajar, Mengajar, dan Meneliti. Yogya karta: Media Akademi.

Tanujaya, B., Mumu, J., Purwati., \& Lohi, F. F. (2017). Development Instruction Quality Of Statistics With Think Pair Share through Lesson Study for Learning Comunity on FKIP UNIPA. Prosiding The 8th International Confrence on Lesson Study 8(1)

Utami, B dkk. (2011). Penerapan Pendidikan Konstruktivisme melalui model Pembelajaran Think Pair Share TPS dalam kegiatan Lesson Study untuk Meningkatkan Kualitas Proses dan hasil Belajar Strategi Belajar Mengajar. Jurnal Inovasi Pendidikan. 12(1): $1-18$ 